\title{
Landscaping Habitat For Humanity Homes: A Community Outreach Project
}

Jodie L. Ramsay, Northern State University

\begin{abstract}
The purpose of this project is to incorporate a community service component into a Biology course at Northern State University (NSU) in Aberdeen, SD. Students in an upper-level botany course (Plant Structure and Function) provide landscaping services to homeowners who have purchased homes through Habitat for Humanity. Homeowner satisfaction with the finished project and student learning are assessed through surveys.
\end{abstract}

Keywords: community service, civic engagement, landscaping, student learning

\section{INTRODUCTION}

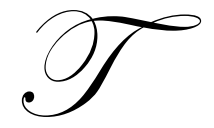

his project is designed to enhance student learning as well as promote civic engagement. Historically, civic engagement was thought to be limited to particular courses such as those in political science. More recently, however, the definition of civic engagement has been broadened to include many types of discipline-specific activities (Avard, 2006). The numbers of college students who are volunteering has increased over the past several years. Roughly $30 \%$ of college students ages 16-24 volunteered in 2005, compared to $28 \%$ of students in 2002. Driving forces behind this increase may include increased servicelearning programs in K-12 schools and those students' observations of the national response to the 2001 terrorist attacks (Farrell, 2006). Studies have shown that high school students who take part in community service are more likely to vote and volunteer as adults as their peers (Ash, 2007). Some of the college students who participate in this project have done extensive volunteer work, while others have not done any volunteering.

Many colleges have active Habitat for Humanity chapters, where students can volunteer to assist with home construction. This project was designed to assist Habitat for Humanity homeowners after their home is completed. Because many Habitat homeowners have never owned a home, they may know little about lawn care and landscaping and often do not have extra funds for such projects. As the students and I prepare to undertake the project each spring, we discuss the effect that landscaping has on property values, water usage, and general beautification of homes.

Habitat for Humanity was founded in 1976 by Millard Fillmore. Habitat is a non-profit organization that provides affordable housing for low-income families. Materials to build the homes are often donated, as is the time of numerous volunteers. Once chosen for the program, each family must put in a certain number of hours of 'sweat equity' towards building their home, and often they assist other potential homeowners as well. Homeowners pay low mortgage payments with no interest, and those monies go towards building other homes. There are now Habitat chapters in over 1500 U.S. cities and 60 other countries. The Aberdeen, SD area chapter of Habitat (HubHabitat) has been in existence for around 10 years. The ninth house was finished in the fall of 2006 (www.hubhabitat.org).

Of the nine existing homes, the five most recently built homes have had the landscaping project done. Due to the fact that Hub Area Habitat for Humanity was unable to complete a home in 2007, landscaping was done for a home built through another local non-profit organization, Homes are Possible, Inc. (www.homesarepossible.org). The goal of this project is to landscape at least one bare area adjacent to a new home per year. 


\section{MATERIALS AND METHODS}

I have several years of greenhouse experience, so I am able to provide advice and information to both students and homeowners. Homeowners whose homes were finished the previous year are contacted each spring to see if they wish to have landscaping done at no cost to them. They are asked to prepare the soil for planting, which may include tilling and/or weeding. The Science Club at NSU provides funding with money raised from a plant sale at which several varieties of houseplants are sold. The houseplants are propagated by student workers and/or students in biology courses. A local nursery provides a substantial discount on landscaping plants and materials. This project spans several weeks of the semester. Several weeks before the end of the semester, students in Biology 351 are given an assignment in which they research types of plants to use for the particular area to be landscaped (Figure 1). Enrollment in this course usually ranges between 15-20 students. Students must present their information to the class. Measurements are taken at the home and a landscape design incorporating many of the students' ideas is drawn up. During the last week of the semester, students do the planting, install edging, and mulch the plants Homeowners are then given advice on how to care for the plants. The following year, the families are contacted to see if they have any questions or concerns regarding their plants (Figure 2). Student learning in Biology 351 is also assessed via a survey (Figure 3, Table 1). The survey includes information specific to landscaping as well as information discussed in class.

\section{Figure 1}

\section{Landscaping Assignment Given to Students in Biology 351.}

\section{Details:}

In order to choose the correct plants for a specific landscaping location, several things must be taken into consideration.

- What type of soil will the plants be placed in?

- How much sun does it get (which side of the house is it on)? Do trees shade the area? The sun is hottest from 11-2; some plants can tolerate sun during that time or several hours of sun during the day, while others require more shade.

- How big of a space is available? Are there windows or other objects that need to be taken into account? Does the plant spread?

- Is there a color scheme that needs to be followed?

- When does the plant flower and how long do the flowers last?

- $\quad$ Are there any special things to be noted about maintenance of the plant?

Perennials are usually labeled as being hardy in a particular zone (per the USDA). The farther south you go, the larger the numbers of the zones are (so something that grows in zone 7 will not be hardy here).

- $\quad$ Find out which hardiness zone Aberdeen is in.

- Use the Brown County soil survey to describe Aberdeen's soil. How might soil texture impact plant growth in this region?

- $\quad$ Find an example of a sun-tolerant perennial and a shade-tolerant perennial that will grow here. Provide a picture and a brief description.

You will receive points for this assignment as well as participating in the planting during the last week of class. 
Figure 2

Follow-up Survey for Habitat for Humanity Homeowners.

Please rate your satisfaction regarding the landscaping done at your home by answering each of the following questions. Please rank these statements from 1 to 5, 1 being strongly disagree, and 5 being strongly agree.

\begin{tabular}{|l|l|}
\hline \multicolumn{1}{|c|}{ STATEMENT } & RATING \\
\hline The plants survived the first winter. & \\
\hline The plants have survived subsequent winters. & \\
\hline The care and maintenance of your plants was explained adequately. & \\
\hline The addition of mulch has limited the amount of weeding required. & \\
\hline The pots of annual flowers provided did well throughout the growing season. & \\
\hline The pots of annual flowers enhanced the look of my yard. & \\
\hline I have re-used the pots in subsequent years. & \\
\hline I would have eventually landscaped the selected area on my own without outside assistance. & \\
\hline Students were careful and courteous while at my home. & \\
\hline I would like additional advice and assistance regarding landscaping. & \\
\hline I am happy with how the landscaping project turned out at my home. & \\
\hline
\end{tabular}

Please comment on any of the statements above.

Figure 3

Survey for students participating in landscape project.

Please rate your knowledge and/or experience in each of the following areas both before and after the landscaping project. Use a scale of 1-5, as described below.

\begin{tabular}{|l|l|l|}
\hline & Before & After \\
\hline Meaning of hardiness zone & & \\
\hline Soil type in Aberdeen & & \\
\hline Sun exposure based on direction (N, S, E, W) & & \\
\hline Weed prevention methods & & \\
\hline Shade-tolerant perennials & & \\
\hline Sun-tolerant perennials & & \\
\hline Proper planting techniques & & \\
\hline
\end{tabular}

Rate your overall experience with this project.

$1=$ no interest, only participated as a class assignment; 5 = highly interested; will use the information learned in the future

2

3

4

5

\section{RESULTS}

In 2007, 14 students participated in the landscaping project. Results of the survey administered are shown in Table 1. For each topic addressed in the survey, student knowledge and experience increased as a result of their participation in this project. 
Table 1

Results of student survey before and after landscaping project, 2007. As per Figure 3, 1 on the scale of 1-5 indicates little interest/experience. The top number indicates the number of students who selected that number; the numbers in parentheses are percentages of students who selected that number (out of 14 students).

\begin{tabular}{|c|c|c|c|c|c|c|c|}
\hline & $\begin{array}{l}\text { Meaning of } \\
\text { hardiness } \\
\text { zone }\end{array}$ & $\begin{array}{l}\text { Soil type in } \\
\text { Aberdeen }\end{array}$ & $\begin{array}{c}\text { Sun } \\
\text { exposure } \\
\text { based on } \\
\text { direction }\end{array}$ & $\begin{array}{c}\text { Weed } \\
\text { prevention } \\
\text { method }\end{array}$ & $\begin{array}{c}\text { Shade- } \\
\text { tolerant } \\
\text { perennials }\end{array}$ & $\begin{array}{c}\text { Sun-tolerant } \\
\text { perennials }\end{array}$ & $\begin{array}{c}\text { Proper } \\
\text { planting } \\
\text { techniques }\end{array}$ \\
\hline $\begin{array}{c}1- \\
\text { before }\end{array}$ & $\begin{array}{c}8 \\
(57.1)\end{array}$ & $\begin{array}{c}8 \\
(57.1)\end{array}$ & $\begin{array}{c}8 \\
(57.1)\end{array}$ & $\begin{array}{c}6 \\
(42.8)\end{array}$ & $\begin{array}{c}8 \\
(57.1)\end{array}$ & $\begin{array}{c}8 \\
(57.1)\end{array}$ & $\begin{array}{c}4 \\
(28.6)\end{array}$ \\
\hline 1-after & $\begin{array}{c}0 \\
(0)\end{array}$ & $\begin{array}{c}0 \\
(0)\end{array}$ & $\begin{array}{c}0 \\
(0)\end{array}$ & $\begin{array}{c}0 \\
(0)\end{array}$ & $\begin{array}{c}0 \\
(0)\end{array}$ & $\begin{array}{c}0 \\
(0)\end{array}$ & $\begin{array}{c}0 \\
(0)\end{array}$ \\
\hline $\begin{array}{c}2- \\
\text { before }\end{array}$ & $\begin{array}{c}2 \\
(14.3) \\
\end{array}$ & $\begin{array}{c}4 \\
(28.5) \\
\end{array}$ & $\begin{array}{c}2 \\
(14.3) \\
\end{array}$ & $\begin{array}{c}5 \\
(35.7) \\
\end{array}$ & $\begin{array}{c}3 \\
(21.4) \\
\end{array}$ & $\begin{array}{c}3 \\
(21.4) \\
\end{array}$ & $\begin{array}{c}3 \\
(21.4) \\
\end{array}$ \\
\hline 2-after & $\begin{array}{c}0 \\
(0)\end{array}$ & $\begin{array}{c}0 \\
(0)\end{array}$ & $\begin{array}{c}1 \\
(7.1)\end{array}$ & $\begin{array}{c}1 \\
(7.1)\end{array}$ & $\begin{array}{c}0 \\
(0)\end{array}$ & $\begin{array}{c}0 \\
(0)\end{array}$ & $\begin{array}{c}0 \\
(0)\end{array}$ \\
\hline $\begin{array}{c}\text { 3- } \\
\text { before }\end{array}$ & $\begin{array}{c}2 \\
(14.3)\end{array}$ & $\begin{array}{c}1 \\
(7.1)\end{array}$ & $\begin{array}{c}2 \\
(14.3)\end{array}$ & $\begin{array}{c}1 \\
(7.1)\end{array}$ & $\begin{array}{c}1 \\
(7.1)\end{array}$ & $\begin{array}{c}1 \\
(7.1)\end{array}$ & $\begin{array}{c}5 \\
(35.7) \\
\end{array}$ \\
\hline 3-after & $\begin{array}{c}2 \\
(14.3) \\
\end{array}$ & $\begin{array}{c}1 \\
(7.1) \\
\end{array}$ & $\begin{array}{c}1 \\
(14.3) \\
\end{array}$ & $\begin{array}{c}3 \\
(21.4) \\
\end{array}$ & $\begin{array}{c}3 \\
(21.4) \\
\end{array}$ & $\begin{array}{c}3 \\
(21.4) \\
\end{array}$ & $\begin{array}{c}2 \\
(14.3) \\
\end{array}$ \\
\hline $\begin{array}{c}\text { 4- } \\
\text { before }\end{array}$ & $\begin{array}{c}1 \\
(7.1)\end{array}$ & $\begin{array}{c}0 \\
(0)\end{array}$ & $\begin{array}{c}1 \\
(7.1)\end{array}$ & $\begin{array}{c}1 \\
(7.1)\end{array}$ & $\begin{array}{c}1 \\
(7.1)\end{array}$ & $\begin{array}{c}1 \\
(7.1)\end{array}$ & $\begin{array}{c}2 \\
(14.3)\end{array}$ \\
\hline 4-after & $\begin{array}{c}5 \\
(35.7)\end{array}$ & $\begin{array}{c}8 \\
(57.1)\end{array}$ & $\begin{array}{c}5 \\
(35.7)\end{array}$ & $\begin{array}{c}6 \\
(42.8)\end{array}$ & $\begin{array}{c}7 \\
(50.0)\end{array}$ & $\begin{array}{c}7 \\
(50.0)\end{array}$ & $\begin{array}{c}6 \\
(42.8)\end{array}$ \\
\hline $\begin{array}{c}5- \\
\text { before }\end{array}$ & $\begin{array}{c}1 \\
(7.1)\end{array}$ & $\begin{array}{c}1 \\
(7.1)\end{array}$ & $\begin{array}{c}1 \\
(7.1)\end{array}$ & $\begin{array}{c}1 \\
(7.1)\end{array}$ & $\begin{array}{c}1 \\
(7.1)\end{array}$ & $\begin{array}{c}1 \\
(7.1)\end{array}$ & $\begin{array}{c}1 \\
(7.1)\end{array}$ \\
\hline 5-after & $\begin{array}{c}7 \\
(50.0)\end{array}$ & $\begin{array}{c}5 \\
(35.7)\end{array}$ & $\begin{array}{c}7 \\
(50.0)\end{array}$ & $\begin{array}{c}4 \\
(28.5)\end{array}$ & $\begin{array}{c}4 \\
(28.5)\end{array}$ & $\begin{array}{c}4 \\
(28.5)\end{array}$ & $\begin{array}{c}6 \\
(42.8)\end{array}$ \\
\hline
\end{tabular}

\section{CONCLUSIONS}

Biology 351 is one of two plant-related courses that students must take at NSU in order to graduate with a Biology degree. Unfortunately, unless they have a vested interested in plants (e.g. they are interested in gardening or are going on to study forestry), some students feel that this is a course that they simply have to take. They don't know what this course will do for them in the long run, as is often the case with introductory courses taken to fulfill general education requirements (Watts, 2006). The landscaping project changes many of their perceptions. Completing the landscaping assignment itself is a requirement, but their attendance on the day of landscaping is worth only a very small percentage of their grade. Interestingly though, in the 6 years this project has been done, all students enrolled in the course have chosen to come and help with the landscaping. Once they start researching the information and learn about the home and family they will be helping, they are enthusiastic about continuing on and seeing the landscaping completed.

To assess student learning, students were asked to complete an anonymous survey relating to various topics we discussed throughout the course of the project. This was done for the first time in 2007. As Table 1 indicates, the number of students who felt they had little knowledge/interest in a particular topic before the project decreased for each item examined in the survey. For example, 57\% of students selected 1 in regards to shade tolerant perennials. After the project was completed, $50 \%$ of the students selected 4 . One student wrote "I'd heard of hardiness zones before but never realized how easily it can be used to select plants for landscaping. Soil types are fascinating (honest!). This has a huge impact on how well a plant will grow and is often overlooked, which is unfortunate. I never really thought about sun and shade tolerance before. All that I learned will be helpful and useful in the future when I landscape around the house I am buying."

Future plans for this project include expanding fundraising to include private donations as well as money donated by the Science Club at NSU, and going back to previously landscaped homes for maintenance and addition 
of new materials. Comments from both students and homeowners indicate that this has been a positive experience for all involved. The Aberdeen community has been supportive of this project as well, as it was featured in the Aberdeen American News (Waltman, 2003). Students gain practical knowledge and experience about landscaping as they help out a deserving family.

\section{ACKNOWLEDGMENTS}

This project is financially supported by the Student Senate, the Science Club, and Faculty and staff of Northern State University. Parkview Nursery of Aberdeen, SD provides plants and materials at a substantial discount. Mulch is provided by the City of Aberdeen.

\section{REFERENCES}

1. $\quad$ Ash, K. 2007. Service Learning. Education Week 26(32):14.

2. Avard, M. 2006. Civic Engagement in the Science Classroom. Journal of College Science Teaching 36(3):12-13.

3. Farrell, E.F. 2996. More College Students are Volunteering. Chronicle of Higher Education 53(10):A40.

4. Waltman, S. 2003. Students Brighten Home. Aberdeen American News. April 29 issue, pages 1A, 10A.

5. Watts, M. 2006. Becoming Educated: Service Learning as Mirror. Pp. 33-54, In: Gibson, C., Editor. Student Engagement and Information Literacy. American Library Association.

6. www.homesarepossible.org

7. www.hubhabitat.org 
NOTES 